\title{
Identification and Strategy Tourism Attractions Memorial Surabaya
}

\author{
Nyoman Lokajaya \\ Doctoral student. \\ Faculty of Economics and Business, \\ University of 17 Agustus 1945 Surabaya. \\ Surabaya, Indonesia; \\ Ida Aju Brahmasari \\ Lecturer of Management Department, \\ Faculty of Economics and Business, \\ University of 17 Agustus 1945 Surabaya, \\ Surabaya, Indonesia; \\ Anis Eliyana \\ Lecturer of Management Department, \\ Faculty of Economics and Business, \\ Airlangga University, Surabaya, Indonesia;
}

\begin{abstract}
The objectives of this study are 1) to identify the area as an object of memorial tourism attraction which triggers a battle event on November 10, 1945, 2) Generate a strategy that supports the attraction of memorial Surabaya tourism. The research method used is qualitative research with a phenomenological approach.

By using the interpretative phenomenological analysis method, it were 1) Obtained 20 objects of memorial tourist attraction which triggered the November 10, 1945 battle events from the Jalan Bubutan (GNI Building, Viaduct) to the Jalan Tunjungan (Siola, Yamato/Majapahit Hotel). 2) Strategies that support the attraction of Surabaya memorial tourism are a) Introduction and promotion of the cultural sites of heritage sites (building heritage sites) Surabaya through the Tourism Information Center, b) Instilling heroic historical values of Surabaya through memorial tours, c) Maintenance of existing cultural heritage, d) Hold a historical river tourism event with a route from the Petekan Bridge to the Jalan Pemuda Bridge (near Gubeng Pojok).
\end{abstract}

Keywords: Identification and Strategy Tourism; memorial tourism; phenomenology approach; interpretative phenomenology analysis. 


\section{INTRODUCTION}

Surabaya has a variety of cultural heritage that is manifested in the form of art, local wisdom, and historical buildings or areas. At present, there are 20 tourist attractions of the city of Surabaya, which are often visited by tourists through program visit of museum and program visit of maritime [1].

The object of program the attraction of this tourism has yet to show a tourism destination the city of Surabaya as the City of Heroes, namely dark tourism as triggered the war on November 10, 1945. Dark tourism in Government Regulation Number 50 of 2011 is mentioned as tourism of memorial [2]

To uncover the memorial tourism opportunities research is needed that aims to 1) Identify the memorial tourist attraction that triggers the November 10, 1945 battle event, 2) Generate strategies that support the Surabaya memorial tourist attraction.

\section{Qualitative research with a phenomenological approach}

Qualitative research with a phenomenological approach is sourced from the study of philosophy. This study aims to understand the meaning of events, symptoms that arise, and interactions for individuals in certain conditions and situations in everyday life in a particular society [3]

The presence of researchers as research instruments is something that can not be separated in the conduct of qualitative research. The presence in the form of participant observation (participant observation) as a feature to study and search for data in the field, required intimate social interaction in people's lives [4].

The phenomenological approach examines entry into the world of meaning that is conceptualized (constructed) within the individual and then acted on in the form of phenomena. A phenomenological approach assumes that for individuals to interact with each other there are many ways of interpreting experience, the meaning of experience shapes the reality of the action that is shown (acted on) [5].

Related to phenomenology, Schutz states that to understand various individual actions, researchers should understand various actions based on various motives underlying the actions. These motives are motives for individual actions, purposeful motives for individual actions. Besides that, it must be understood various conditions underlying the emergence of both motifs [6].

\section{Strategy Management Concepts}

Strategy management is a series of managerial decisions and actions that determine the company's long-term performance, which includes environmental observation, strategy formulation, strategy implementation, and evaluation and control [7].

Strategy management is a number of decisions and actions that lead to the preparation of a strategy or a number of effective strategies to help achieve company goals [8]. 
This understanding shows the management of strategy as a framework for resolving every strategic problem in the company, especially for competition, so managers are invited to think more creatively or think strategically to produce alternative considerations to solve problems more thoroughly and profitably.

\section{The Concept of Tourism Attractions}

Based on Government Regulation of the Republic of Indonesia Number 50 the Year 2011 Concerning the National Tourism Development Master Plan for 2010 - 2025 article 14 it is stated that tourist attractions include natural tourism attractions, cultural tourism attractions, and manmade tourist attractions [9].

\section{Natural Tourism Attraction}

The attraction of natural tourism is a tourist attraction in the form of diversity and uniqueness of the natural environment. Natural attractions, including:

a. The attraction of nature tourism based on the potential of diversity and the uniqueness of the natural environment in the territorial waters of the sea, in the form of:

- Coastal landscape

- Seascapes, both waters around the coast and offshore that reach certain distances that have maritime potential

- Water pool and seabed

b. The attraction of nature tourism based on the potential diversity and uniqueness of the natural environment in the mainland, which includes:

- Mountains and natural forests / national parks / nature tourism parks / grand forest parks

- River and lake waters

- Plantation

- Agriculture

- Special landscapes

\section{Cultural Tourism Attractions}

The attraction of cultural tourism is the tourist attraction in the form of the results of human creativity, taste, and initiative as a cultural being.

Cultural tourism attractions, including:

a. Tangible cultural tourism attractions, which include:

1. Cultural heritage, which includes:

i. Cultural heritage objects are natural objects and/or man-made objects, both movable and immovable, in the form of a unit or group, or parts thereof, or the remnants that have a close relationship with culture and the history of human development.

ii. Cultural heritage buildings are built structures made of natural objects or man-made objects to meet the needs of walled and/or non-walled spaces and roofed. 
iii. Cultural heritage structures are built structures made from natural objects and / or man-made objects to meet the needs of activity space that is integrated with nature, facilities, and infrastructure to accommodate human needs.

iv. Cultural heritage sites are locations that are on land and / or in water that contain objects of cultural heritage, cultural heritage buildings, and / or structures of cultural reserves as a result of human activities or evidence of past events.

v. A cultural preservation area is a geographical space unit that has 2 (two) or more cultural heritage sites that are located close together and/or show distinctive spatial characteristics.

2. Traditional villages with unique customs and cultural traditions of the people

3. Museum

b. The intangible cultural tourism attractions which include:

1. The traditional life and traditions of the people and the cultural activities of the people that are specific to an area/place

2. Art

c. Tourism Attractions of Man-Made Results

The attraction of man-made products is a special tourist attraction which is an artificial creation (artificially created) and other human activities outside the realm of natural and cultural tourism.

The tourist attractions of man-made/special results include:

1. Recreational and entertainment facilities/theme parks, which are facilities related to motivation for recreation, entertainment, and hobby distribution

2. Integrated resort facility, which is a resort area with supporting components that form an integrated area

3. Recreational and sports facilities

\section{General Observations}

\section{RESEARCH METHOD}

As a first step of the study, general observations were carried out, starting with the geographical location of the cultural heritage area, the history, and development of the city of Surabaya, the events leading up to the November 10,1945 battle, and the development of tourism in the city of Surabaya.

\section{Determination of research subjects}

Informants in this study consisted of 4 people from the Surabaya City Culture and Tourism Office, 1 historical witness and 1 tourism business person. 


\section{In-depth interviews}

Retrieval of data through in-depth interviews will explore all problems in the form of open conversation discourse with conditions that are free, relaxed, not depressed, but leads to a dialogue, discussion to find causal relationships between themes or between substances based on the data that has been found, so researchers only lead to the topic of the conversation and not control answers from informants or research subjects.

\section{Documentation Activities}

In addition to collecting data through observation and interviews, researchers also carried out documentation activities, in the form of taking photos related to this research, through in-depth searches of facts and phenomena from research objects, so that user data would be found as analytical material in this study.

\section{Check data validity}

Checking the validity of the data is carried out by following the following procedures [10]:

1. Triangulation is a data validity checking technique that utilizes other parties outside the data as a comparison to the data.

2. Research reflexivity, explains to others who have an understanding of the reasons for using theories and research methods.

3. Member checking is a data validity checking technique by discussing the results of research through formal and informal discussions.

4. Thick and rich description, is the stage of the researcher explaining in detail the results of the study.

\section{INTERPRETATIVE PHENOMENOLOGICAL ANALYSIS}

After checking the validity of the data, the identification stage of the meaning is called the data reduction stage. In phenomenology, this stage is called Interpretative Phenomenological Analysis.

The steps of this analysis are as follows:

1. Reading and Re-reading, namely writing interview transcripts from audio recordings into transcripts in written form

2. Initial Noting, which records everything interesting in the transcript

3. Developing Emergent Themes, namely developing the emergence of themes

4. Searching for connection across emergent themes, i.e. looking for meaning from the sketches of the themes that emerge and are mutually compatible

5. Moving the next cases, i.e. moving to the next participant

6. Looking for patterns across cases, i.e. create a master table of themes for one case or group of cases

\section{RESULTS AND ANALYSIS \\ Identification of Memorial Tourism Attraction Objects}

The results of the identification, obtained 20 objects of memorial tourist attraction which triggered the November 10, 1945 battle events as follows: 
Table 1. Tourism Attractions of Memorial Surabaya Objects

\begin{tabular}{|c|c|}
\hline Object Attraction & Memorial event \\
\hline Jl.Bubutan (GNI Building, Viaduct Jl. Bubutan) & $\begin{array}{l}\text { Establishment of the Youth of the Republic of Indonesia (PRI) } \\
\text { (September } 4,1945 \text { ) } \\
\text { Design a giant meeting on the Tambaksari field } \\
\text { Fierce battles against the Japanese army (October 1,1945) }\end{array}$ \\
\hline Jl.Perak Barat (Morokrembangan Field) & Allied landing land (October 25,1945$)$ \\
\hline Jl.Perak Timur (Tanjung Perak) & $\begin{array}{l}\text { Allied landing land (October 25, 1945) } \\
\text { Detention of motorboat British (Allied) troops }\end{array}$ \\
\hline Jl.Jakarta (House in Jl. Jakarta no. 5) & Negotiations with allies \\
\hline Kalimas Harbor & $\begin{array}{l}\text { The landing of British troops on behalf of the Allies (October } \\
25,1945)\end{array}$ \\
\hline $\begin{array}{l}\text { Kodikal (Complex Ujung: Pasiran Field, } \\
\text { Ujung) }\end{array}$ & $\begin{array}{l}\text { A Japanese prisoner who was disarmed by arek-arek } \\
\text { Suroboyo } \\
\text { The takeover of PAL belongs to RI }\end{array}$ \\
\hline Jl.KH Mas Mansyur (Fort Leaning Al-Irshad) & $\begin{array}{l}\text { The place of Japanese captives who were disarmed by arek- } \\
\text { arek Suroboyo }\end{array}$ \\
\hline $\begin{array}{l}\text { Jl.Tambaksari Field (Now Bui } \\
10 \text { Nopember 1945) }\end{array}$ & meeting on September 11, 1945 \\
\hline
\end{tabular}

Jl.Rajawali (Telkom Surabaya North Office, Internatio Building / PT. Aneka Niaga, Areas around Jembatan Merah)

Jl.Pahlawan (Kenpetai Building, Area Around Tugu Pahlawan, Domei Office Jl.Pahlawan no. 28, Viaduct Jl.Pahlawan, Governor's Office)

Jl.Stasiun Gubeng Lama (Gubeng Pojok Japanese Marine Headquarters)

Jl. Biliton (Residential House Jl.Biliton no. 7)

Jl.Kayon (Kayon Bridge-Brantas Hotel)

Jl.Pemuda (RRI Surabaya Building)

Jl.Darmo (SMP/SMA Santa Maria)

Dwelling House Jl. Kaliasin no. 119 (now Jl. Basuki Rahmat)

Jl.Mawar (Residential House Jl. Rose no. 12)

Jl.Embong Malang (Press Museum)

Jl.Tidar (Residential House Jl. Widodaren no. 1, Don Bosco Building)

Jl.Tunjungan (Siola, Yamato / Majapahit Hotel)
Fierce battle against British (Allied) troops (October 29, 1945)

Brigadier General Mallaby lost his mind

The disappearance of Brigadier General Mallaby

Death of Brigadier General Mallaby (October 30, 1945)

A fierce battle against the Japanese army, BKR Headquarters

(October 1, 1945)

Disarmament of the Japanese army

Rebellion radio transmitters and news agencies

Flying the Red and White

Establishment of TKR (October 5, 1945)

Contact and Negotiations with Allies

Fierce battles against the Japanese army (October 1, 1945)

Disarmament of the Japanese army ( October 2, 1945)

Formation of a line of uprisings by the Indonesian people led

by Bung Tomo

TKR defense base (October 5, 1945)

Fierce battle against British (Allied) troops

Bung Tomo's speech

Youth meetings, students

Formation of a Student Army

TRIP Headquarters

KNI office

Radio Rebels as command of the battle against the Allies

Radio news transmitter

Answer Governor Suryo rejects Allied ultimatum (November 9, 1945 night)

Formation and Headquarters of PRI (September 4, 1945)

Submission of the Japanese government to Indonesia and disarmament

Incident and Flag Tearing (September 19, 1945)

Above the hotel, Allied aircraft spread pamphlets to surrender

to arek-arek Suroboyo (November 9, 1945) 
Lokajaya, N., Brahmasari, I. A. \& Eliyana, A. (2020) Identification and Strategy Tourism Attractions Memorial Surabaya. Archives of Business Research, 8(4). 18-25

\section{Understanding of Themes and Meanings}

The informant's understanding in the form of themes and meanings that underlie the Identification and strategy tourism attractions of memorial Surabaya are as follows:

Table 2. Themes and Meanings Tourism Attractions of Memorial Surabaya

\begin{tabular}{cl}
\hline Theme & \multicolumn{1}{c}{ Meanings } \\
\hline & $\begin{array}{l}\text { The area of cultural heritage sites (built heritage sites) that complement other tourism } \\
\text { destinations in the city of Surabaya }\end{array}$ \\
Attraction & $\begin{array}{l}\text { Heroic historical value } \\
\text { Preserved cultural heritage } \\
\text { River tourism that supports tourism destinations, heritage sites (built heritages sites) }\end{array}$ \\
\hline
\end{tabular}

Understanding informants in the form of themes and meanings, strategies that support Surabaya's memorial tourism attraction can be arranged as follows:

1. Introduction and promotion of Surabaya's heritage area (built heritage sites) through the Tourism Information Center (TIC),

2. Instilling heroic historical values of Surabaya through memorial tours,

3. Maintenance of existing cultural reserves,

4. Holding a historical river tourism event with a route from the Petekan Bridge to the Jalan Pemuda Bridge (near Gubeng Pojok).

\section{Conclusion}

\section{CONCLUSION AND SUGGESTION}

Based on the research objectives, it can be concluded as follows:

1. Obtained 20 objects of memorial tourist attraction which triggered the November 10, 1945 battle events from the Jalan Bubutan (GNI Building, Viaduct) to the Jalan Tunjungan (Siola, Yamato/ Majapahit Hotel)

1. Strategies that support Surabaya's memorial tourism attraction are as follows:

a. Introduction and promotion of the cultural sites of heritage sites (building heritage sites) Surabaya through the Tourism Information Center (TIC),

b. Instilling heroic historical values of Surabaya through memorial tours,

c. Maintenance of existing cultural reserves,

d. Holding a historical river tour with a route from the Petekan Bridge to the Jalan Pemuda Bridge (near Gubeng Pojok).

\section{Suggestion}

Tourism sells more services to meet the needs and desires of tourists that are invisible (intangible), and the characteristics of goods and services are very different, therefore it requires people who are aware of tourism and feel they have a tourist destination so that every visitor who comes can be well served and is expected to provide good recommendations (word of mouth) to the next prospective visitors.

\section{References}

1. Pemerintah Kota Surabaya, Peraturan Walikota Surabaya nomor 34 Tahun 2019 Tentang Rencana Kerja Pemerintah Daerah (RKPD) Kota Surabaya Tahun 2019, 2019. p. 125 
2. Presiden Republik Indonesia, Penjelasan Peraturan Pemerintah Nomor 50 Tahun 2011 pasal 14 tentang Rencana Induk Pembangunan Kepariwisataan Nasional Tahun 2010-2025, 2011. p. 11

3. Fatchan, A, Metode Penelitian Kualitatif Beserta Contoh Proposal Skripsi, Tesis dan Disertasi. Jenggala Pustaka Utama, Surabaya, 2011. p. 48

4. Bogdan, Robert C. dan Biklen Kopp Sari, Qualitative Research for Education: An Introduction to Theory and Methods. Allyn and Bacon, Inc, Boston London, 1982. p. 3

5. Collin, F., Social Reality. Routledge, New York, 1997. p. 217

6. Schutz, Alfred, The Phenomenology of The Social World. Heinemann Educational Book, London, 1972. p.228-229

7. Hunger, J David dan Thomas L. Wheelen, Manjemen Strategis. Penerbit Andi, Yogyakarta, 2003. p. 27

8. Jauch, Lawrence R. dan William F. Glueck, Manajemen Strategis dan Kebijakan Perusahaan. Erlangga, Jakarta, 1999 , p. 6

9. Presiden Republik Indonesia, Penjelasan Peraturan Pemerintah Nomor 50 Tahun 2011 pasal 14 tentang Rencana Induk Pembangunan Kepariwisataan Nasional Tahun 2010-2025, 2011. p. 7-11

10. Creswell, John W, Penelitian Kualitatif dan Desain Riset: Memilih di antara Lima Pendekatan. Edisi Indonesia, cetakan 1, Pustaka Pelajar, Yogyakarta, 2015. P. 350-35 